\title{
Fostering Passion Among First Year Engineering Students
}

Quamrul H. Mazumder, University of Michigan-Flint, USA Mary Jo Finney, University of Michigan-Flint, USA

\begin{abstract}
Engineering is a complex field of study. Declining enrollment in engineering programs in the United States is of concern and understanding the various factors that contribute to this decline is in order. Fostering a higher level of student engagement with the content may foster passion towards engineering which could increase academic competency as well as sustained interest in remaining in the profession. This study examined the role of passion toward engineering content on students' overall academic performance in an introductory course taught to university and high school students. A pre-test, post-test, weekly surveys and periodic classroom observation measured levels of passion in the student, classmates, and professor. Mid-semester feedback prompted the professor to adjust his teaching for the purpose of infusing greater student passion towards the content. Results suggest that student passion in both settings fluctuated widely from week to week perhaps due to variable interest in the specific topic. Overall, high school students' level of passion remained more stable than that of university students and they performed better academically. Among university students, higher passion was not linked to higher academic performance. Professor's passion was highly valued by students though it did not increase their own passion.
\end{abstract}

\section{INTRODUCTION}

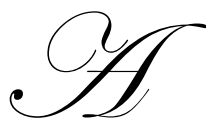

$\mathrm{n}$ urgent need for qualified engineers has sounded the alarm for educators to focus not only on students' academic success but on preparing professionals who will stay in the field. Reports indicating a serious decline in undergraduate enrollment in engineering ${ }^{1,2,3}$ underscore the need for engineering education to focus attention toward not only what is taught but how content is taught, with the aim to boost student enrollment and retention in engineering programs, as well as to ensure adequate preparation for what is a demanding profession. While mastery of technical skills is essential to employability and competence, interest and satisfaction in the work may be what ultimately sustains a robust workforce.

Attention to affective dimensions of student learning is likely to shed broader light on what it takes to spark interest, sustain attention, and foster passion toward engineering as a career. Furthermore, given that passion for learning may not be as much taught as it is exuded by the professor, a professor's own self-reflection is both compelling for the individual who teaches ${ }^{4}$ and critical to teaching excellence ${ }^{5}$. Students' perception of passion level of a professor can greatly influence the overall learning process; students' reflection of professor's passion was found to be more relevant than professor's self-reflection and presented in this paper. In the interest of advancing the engineering profession, attracting and retaining the best students, and creating a sustainable workforce of qualified individuals who bring a passion to the profession, this study explored the role of fostering passion among first year engineering students in academic performance.

\section{LITERATURE REVIEW}

There is considerable research on various aspects of engineering education including studies of the learner, the learning environment and, to a lesser extent, the teacher. Each of these three areas, including the role of affect in learning, informs the research questions that undergird this study and are reviewed here. 
Studies examining the learner underscore the variation in learning styles (i.e. inductive, deductive, active, reflective, sequential and global) and suggest the cross-cutting theme of engagement as critical to effective learning 6,7 . In response to accommodating different learning styles, studies have looked at methods for involving students beyond listening to lecture. From an attempt to make engineering fun ${ }^{8}$ to examination of indicators of engineering students' persistence ${ }^{9}$, there is an underlying focus on students' direct involvement in learning.

A review of research on the learning environment, in particular active learning ${ }^{10}$, offers insight into the efficacy of active, collaborative, cooperative and problem-based learning. Though there is support for each type of learning environment, the evidence is broad and uneven. Problem-based learning, in particular, has been studied as it relates to students' readiness for the profession ${ }^{11}$. A study of simulation learning by Davies ${ }^{12}$ revealed that learning was achieved only if sufficient time was allowed for deep engagement to develop. In each case, the efficacy of the learning environment hinged on the level of student engagement it fostered.

Research on the role of teacher in student learning demonstrates that, aside from content and technique, the teacher poses yet another variable. A study of the role of faculty interaction and feedback on student gains ${ }^{13}$ demonstrated that while climate surrounding peer and instructor in the classroom environment were not linked to student gains, the influence of this climate on instructor interaction and feedback were significantly associated with learning. In a study examining undergraduate views of excellence in engineering education ${ }^{14}$, the effect of teacher was explored pointing to students' expectations that professors feel the audience and convey excitement for the content. From the teachers' perspectives, more emphasis should be placed on cultivating student interest in wanting to learn ${ }^{15}$.

In a special issue of Educational Psychology Review focused on the role of affect in learning, Ainley ${ }^{16}$ draws on her robust research in the role of students' interest, engagement, motivation and affect on cognition to underscore that central to understanding education is the role of affect. Affective factors such as interest and motivation have been studied regarding their influence on student success in general ${ }^{17,18,19}$. Interest has been shown to be related to attention but not necessarily to positive affect. Furthermore, interest has been defined as a situational and often fleeting emotion.

With respect to learning of engineering and science in particular, Felder \& Brent ${ }^{20}$ highlight several models that converge on the notion that there are emotional and social influences on intellectual development in these particular content areas. A review of the literature did not, however, reveal any studies focused specifically on the role of passion toward content and its effect on learning engineering, thus, the following research questions were developed.

\section{RESEARCH QUESTIONS}

This study was guided by the following four research questions:

1. To what extent does a student's sense of passion toward learning affect academic performance?

2. To what extent does the professor's passion for teaching affect student learning?

3. Does students' perception of their professor's passion for teaching affect their learning?

4. Does students' perception of their classmate's passion for learning affect their individual level of passion for learning?

While the design and data gathering focused on answering all four questions, this paper focuses specifically on the students' individual sense of passion and its link to their academic performance.

In order to discuss the variation between attention, interest, engagement, and passion, the researchers created a hierarchical model, as seen in Figure 1, which identifies four levels of learner engagement. The lowest level characterizes those students who are physically present in class but inattentive and not engaged. The next level describes those students who are paying attention but not strongly engaged in the learning. The third level depicts those students who are actively engaged and display interest in the classroom discussion and activity. The fourth level characterizes those students who are passionate about the topic, class, and learning. 


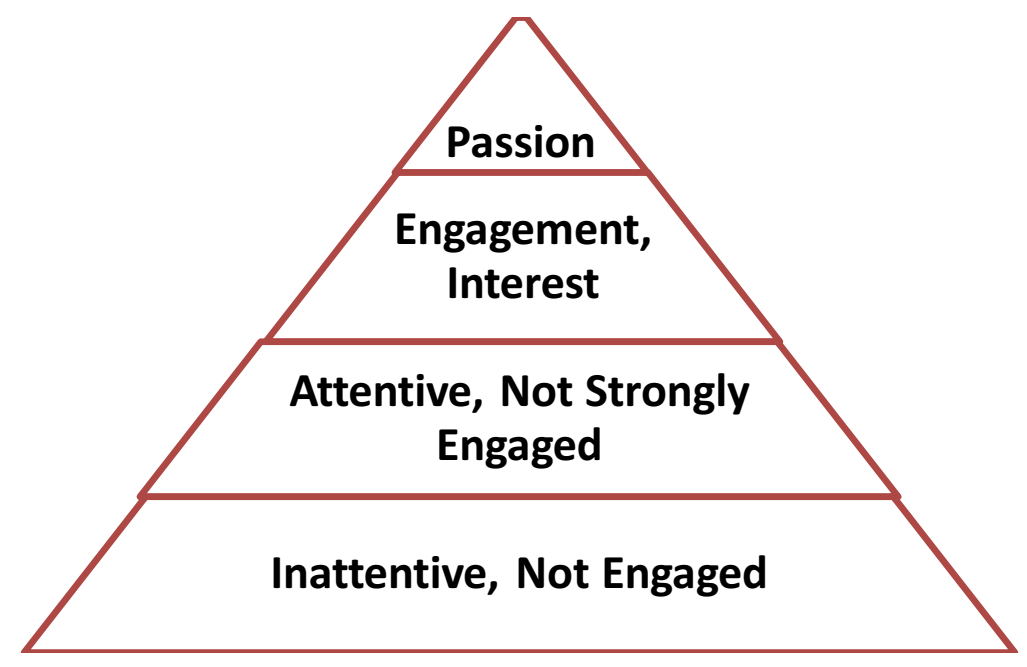

Figure 1: Levels of Student Engagement in the Classroom

This nuanced view of engagement provides a mechanism for considering how the degree of engagement might be characterized, measured, and examined as it relates to academic performance.

\section{SUBJECTS}

Participants in this study included an engineering professor and students enrolled in two sections of an introductory engineering course. The course is designed to survey engineering topics for the purpose of introducing students to basic concepts, terms, and aspects of engineering.

Both sections of the introductory course were identical in content, textbook, assignments, and exams but differed in two ways. First, one section was enrolled by a cohort of nineteen high school students including seventeen seniors and two juniors identified as interested in the study of engineering. These high school students are academically similar as they have completed advanced level courses such as AP courses and were dual enrolled in university. The other section was enrolled by university students. The second distinction was in the delivery format. The university section began each class session with a live telecast lecture from an off-site professor for the first 30 minutes and the remaining 45 minutes were taught face-to-face by the professor involved in this study. The high school section was taught solely in a face-to-face context by the engineering professor involved in this study.

Although the distance learning classroom had several guest lecturers during first 40 minutes of the class, the remaining 35 minutes of the lecture was presented by a single professor in the classroom throughour the semester. Students were asked about the level of passion of the single professor who presented the material in the classroom.

\section{DATA COLLECTION INSTRUMENTS}

Data for this study included a pre/post written survey, weekly surveys, and classroom observation. The Prel Post-Test Questionnaire for Student Assessment of Passion is included as Appendix 1.

The 12-item pre/post- written survey probed students' interest in learning engineering, overall importance of passion to their learning, perception of their professor's and classmates' interest in engineering, the importance of professor and classmates' interest to the students' own learning, and ranking of what they considered to be most important to their interest and learning of engineering among the following: topics, materials, professor interest, professor knowledge, and classmates' interest. 
The 3-item weekly written survey probed students' perception of passion toward the content, as well as their perceptions of the professor's and classmates' level of passion toward content that particular week.

Classroom observation was conducted to observe professor's style of teaching, level of student engagement and interaction, and any aspects of the classroom environment that may contribute to a passionate disposition toward learning engineering. Observations were conducted by the non-teaching researcher as a non-participant observer and yielded detailed field notes including often verbatim transcription of professor and student interaction.

\section{PROCEDURES}

The pre-survey was administered in the first week of the semester at the beginning of the class session. Weekly surveys were administered for twelve consecutive weeks during the last five minutes of each class period. The post-survey was administered during the last week of class at the beginning of the class period. All surveys were administered by either the researcher or a research assistant after the professor had left the room. Classroom observations were conducted only by the researcher twice during the semester in each section of the course.

At two points during the semester, data from the weekly survey results and classroom observation were provided to the professor. This mid-semester feedback was reported to the professor for the purpose of monitoring shifts or changes in students' sense of passion toward the content so that he could, if necessary, adjust his teaching to foster greater passion for engineering content.

Averages of student survey responses were calculated for the three categories that included self-rating of passion, student perception of classmates' passion and perception of professor's level of passion. Possible responses ranged from (1) not engaged, (2) paying attention but not particularly engaged, (3) engaged and somewhat interested, or (4) passionately interested and engaged.

Results from the first reporting of data provided evidence that, across both sections, students' sense of passion toward engineering was moderate. The classroom observation and professor's own reflection on his teaching led him to work to elevate student passion to a higher level. His preference for active student participation in discussion, along with the goal of increasing student passion for the content, led to the introduction of a new tool for fostering active discussion, an anticipation guide.

An anticipation guide is a written hand-out of eight to ten statements, crafted by the professor, about which the student is asked to agree (A) or disagree (D). The statements are typically derived from textbook content about to be studied and include both accurate and inaccurate statements. Unlike true/false statements, anticipation guide statements are crafted in such a way that they invite scrutiny and are arguably somewhat ambiguous. Procedurally, students are given approximately 2-3 minutes to fill out the anticipation guide and then a discussion ensues (in pairs, small groups, or at the whole class level) with students sharing their different responses and rationale for their thinking.

The purpose of the anticipation guide is to induce disequilibrium in the students. By engaging students in discussion that does not immediately accept or refute their answers as being correct, students can openly explore content and listen to a range of plausible answers. Given this professor's interest in fostering student discussion of content as opposed to merely listening to lectures, the anticipation guide was intended to infuse passionate participation in discussion.

Though the anticipation guide was used only once, its underlying function of encouraging prediction and guessing - without penalty - was evident in the subsequent classroom observation where the professor conducted class discussion that invited multiple possible responses to questions and invited exploration of more than one plausible response. Although the anticipation guide may have influenced the overall learning environment, the effectiveness is not conclusive and therefore not presented in this paper. 


\section{LIMITATIONS}

Since the intent of this study was not to test the efficacy of a particular teaching style in advancing student passion, results of the classroom observation were reported only as evidence of the context in which these students were learning rather than as direct evidence in support of how to teach engineering. If passion is important to learning, then further study of particular teaching methodologies that infuse passion into the learning are necessary.

Furthermore, given that the study was not designed with an experimental control group, no direct comparisons or tests of significant difference could be made. As such, the results are descriptive and do not offer definitive conclusion nor are results widely generalizable.

\section{DATA ANALYSIS}

Data from the weekly surveys was tabulated and is reported as descriptive statistics representing a graphic view of changes from one week to the next within each section of the course. While data from the classroom observations provided important feedback in the midst of teaching and were utilized to inform the emergent teaching design of the study ${ }^{21}$, it was beyond the scope of this paper to analyze teaching patterns in direct relation to weekly survey responses.

In examining overall change in passion toward engineering as a pre/post measure, a set of six distinct passion dispositions were identified based on student responses to the following three items on the pre- and postsurveys:

What is your current interest in engineering?

Possible responses included:

(1) not very interested,

(2) somewhat interested

(3) very interested

(4) passionate

In describing myself, I would say I am:

Possible responses included:

(1) not very passionate about anything

(2) somewhat passionate about most things

(3) passionate about most things

(4) very passionate about everything

How important is it to you that you are passionate about what you are learning?

Possible responses included:

(1) not important

(2) somewhat important

(3) it's nice but not necessary

(4) I cannot learn if I am not passionate about what I am learning

Based on the student's responses to each of these three items, the student was placed into one of the following six passion dispositions:

Passion Disposition \#1 Not very interested in engineering

Not very passionate about anything

Passion not important to learning

Passion Disposition \#2 Somewhat interested in engineering

Somewhat passionate about some things

Passion somewhat important to learning 
Passion Disposition \#3 Passionate about engineering

Very passionate about everything

Cannot learn if not passionate about content

Passion Disposition \#4 Not very interested in engineering

Not very passionate, somewhat passionate, very passionate

Passion unimportant, somewhat important, or essential to learning

Passion Disposition \#5 Somewhat interested in engineering

Not very passionate, somewhat passionate, very passionate

Passion unimportant, somewhat important, or essential to learning

Passion Disposition \#6 Passionate about engineering

Not very passionate, somewhat passionate, very passionate

Passion unimportant, somewhat important, or essential to learning

Descriptive statistics were run by disposition group. Since a student's passion disposition may have changed from beginning to end of the semester, descriptive statistics comparing pre- to post- survey were run in order to analyze the extent to which passion dispositions remained stable or changed.

In order to examine the effect of passion on academic performance, a mean final exam score of each passion disposition group was calculated and examined. Due to the comprehensive nature of the final examination for this class, the final exam score is a stronger indicator of academic performance than the composite score, which contains points for attendance, homework, group activities and may not accurately reflect an individual student's academic performance.

\section{RESULTS}

The following figures depict results of the weekly surveys reporting student perception of passion, classmates' passion, and professor's passion, by course section. Weeks where no data is given were student break weeks.

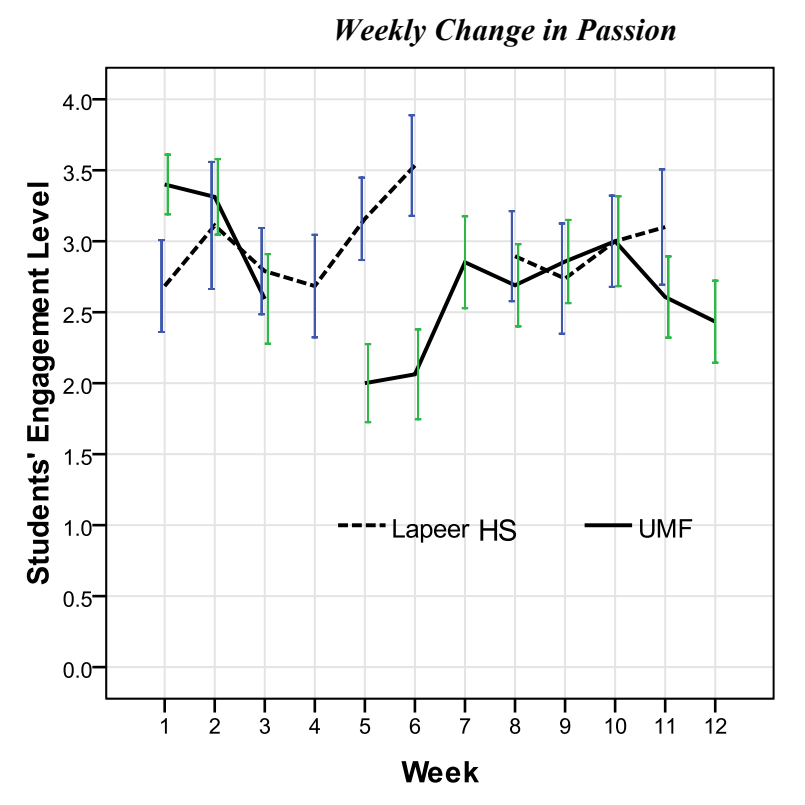

Error bars: $95 \% \mathrm{Cl}$

Figure 2: Weekly survey of students' level of passion 
In both settings, student passion varied from week to week as shown in Figure 2. While there is no discernible pattern to the variation, both settings show fluctuation from week to week. There was no data collected during week 7 fro Lapper High school students and week 4 for university of Michiagn students as the students went to a field trip. University of Michigan Flint students reported lower level of engagement during week 5, 6 and 7 that may be due to the complex subject material presented by the guest lecturers during that time. The lecture topics were nuclear engineering and naval architecture and marine engineering that were less interesting to the students. Student engagement levels were similar during the first 3 weeks of class and last 4 weeks of class.

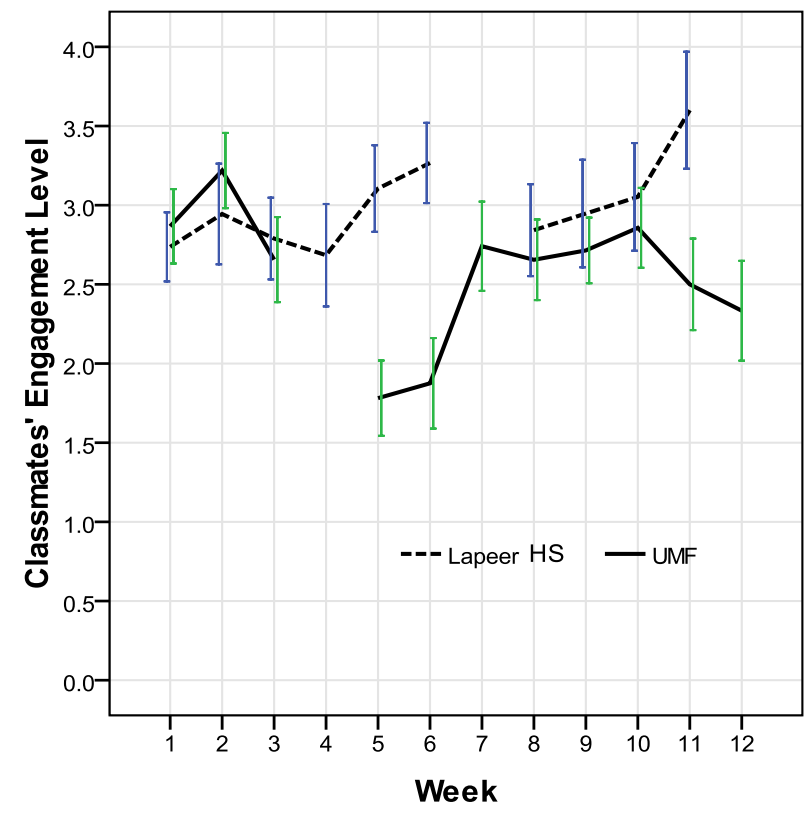

Error bars: $95 \% \mathrm{Cl}$

Figure 3: Weekly survey of classmates' level of passion

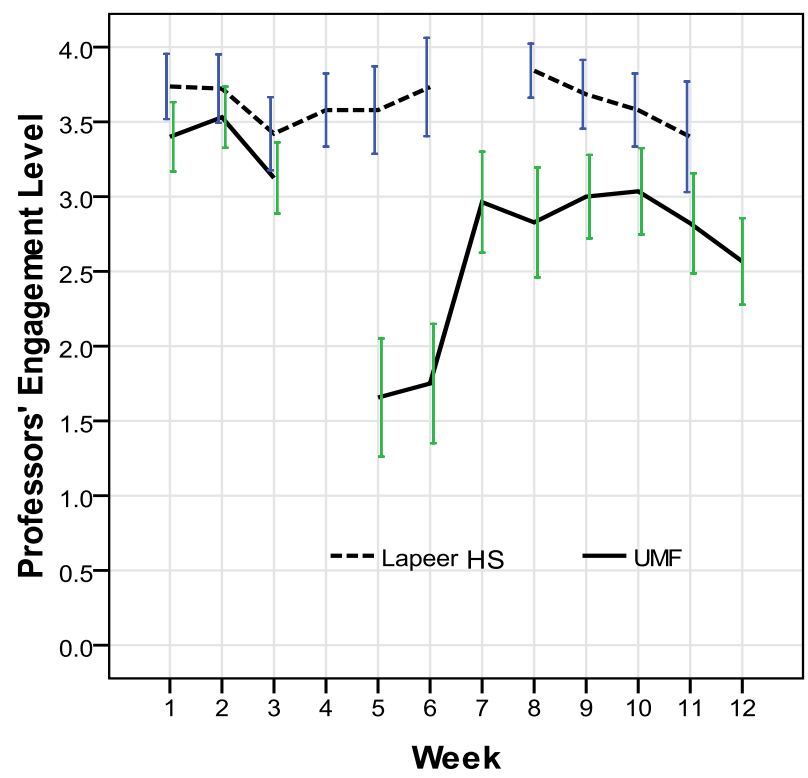

Error bars: $95 \% \mathrm{Cl}$

Figure 4: Weekly survey of professor's level of engagement 
Classmates' level of passion appeared to be consistently higher in the high school setting with somewhat less variation from week to week than in the university setting as shown in Figure 3.

Classmates' engagement levels were lower for university students during week 5 through 11 compared to high school students that is somewhat similar to figure 2 above may be due to similar reasons stated in the pargraph above.

Students' perceptions of the professor's level of passion were consistently high and stable in the high school setting as presented in Figure 4. Though somewhat lower in the university setting, aside from weeks 5 and 6 , students' rating of the professor's passion remained high.

\section{Overall Change in Passion}

In order to examine overall change in passion from the beginning to end of the course, it is important to note how many students were represented in each of the passion dispositions. On the pre-survey, there were no students in Passion Disposition \#1 or \#3. In the high school setting, students fell into either Passion Disposition, \#2, $\# 5$ or \#6 on both pre- and post-surveys. In the university setting, students fell into Passion Dispositions \#2, \#5 or \#6. In the post-survey, the same dispositions were represented but some students fell into Passion Disposition \#4.

Table 1: Comparison of change in passion before and after the course

\begin{tabular}{|l|c|c|c|c|}
\hline Passion Disposition & $\begin{array}{c}\text { High School } \\
\text { PRE-Course } \\
\text { Assessment }\end{array}$ & $\begin{array}{c}\text { High School } \\
\text { POST-Course } \\
\text { Assessment }\end{array}$ & $\begin{array}{c}\text { University } \\
\text { PRE-Course } \\
\text { Assessment }\end{array}$ & $\begin{array}{c}\text { University } \\
\text { POST-Course } \\
\text { Assessment }\end{array}$ \\
\hline Group 2 & $78 \%(15)$ & $57.9 \%(11)$ & $37.5 \%(13)$ & $50 \%(16)$ \\
\hline Group 4 & None & None & None & $10.7 \%(4)$ \\
\hline Group 5 & $10.5 \%(2)$ & $26.3 \%(5)$ & $31.2 \%(10)$ & $28.6 \%(9)$ \\
\hline Group 6 & $10.5 \%(2)$ & $15.8 \%(3)$ & $31.2 \%(10)$ & $10.6 \%(4)$ \\
\hline
\end{tabular}

The passion level of students in Group 2 decreased from $78 \%$ to $57.9 \%$ among high school students, yet increased from $37.5 \%$ to $50 \%$ among university students. The percentage of students in Groups 5 and 6 increased for high school but decreased for university students.

\section{Passion and Academic Performance}

Table 2: Mean Final examination scores of students with pre-course passion dispositions

\begin{tabular}{|l|c|c|c|c|}
\hline Passion Disposition & $\begin{array}{c}\text { High School } \\
\text { (Mean Scores) }\end{array}$ & $\begin{array}{c}\text { High School } \\
\text { (Std. Dev) }\end{array}$ & $\begin{array}{c}\text { University } \\
\text { (Mean Score) }\end{array}$ & $\begin{array}{c}\text { University } \\
\text { (Std. Dev) }\end{array}$ \\
\hline Group 2 & 65.87 & 13.08 & 83 & 5.22 \\
\hline Group 5 & 81 & 16.97 & 75.30 & 20.41 \\
\hline Group 6 & 95 & 12.728 & 78.30 & 10.05 \\
\hline Mean & 70.5 & & 79.2 & \\
\hline
\end{tabular}

Analysis of academic performance reveals that, overall, high school students performed lower than university students. High passion high school students performed best with those somewhat passionate about engineering but not passionate about learning or other things scoring somewhat lower. High school students who were somewhat passionate across the board scored lowest. University students who were somewhat passionate across the board scored highest. Those students highly passionate about engineering scored next highest. Students somewhat passionate about engineering but not passionate about learning or in general scored lowest. A comparison of pre-course disposition to final exam score is presented in the "Passion \& Academic Performance" section later in this paper, as this comparison may indicate meaningful changes occurred during the class. 


\section{Influence of Classmates' Level of Passion}

Table 3: Cross tab of classmates' level of passion towards individual student learning

\begin{tabular}{|c|c|c|c|c|c|c|}
\hline & & \multicolumn{2}{|c|}{ Classmates' passion level (after) } & \multicolumn{3}{|c|}{ Importance to learning (after) } \\
\hline \multirow{3}{*}{$\begin{array}{l}\text { Classmates' } \\
\text { passion } \\
\text { level(before) }\end{array}$} & & Some/very & Passionate & $\begin{array}{c}\text { Not } \\
\text { Important }\end{array}$ & Some/very & $\begin{array}{l}\text { Extremely } \\
\text { Important }\end{array}$ \\
\hline & Some/very & 42 & 0 & $\mathrm{~N} / \mathrm{A}$ & N/A & N/A \\
\hline & Passionate & 4 & 1 & $\mathrm{~N} / \mathrm{A}$ & $\mathrm{N} / \mathrm{A}$ & $\mathrm{N} / \mathrm{A}$ \\
\hline \multirow{2}{*}{$\begin{array}{l}\text { Importance to } \\
\text { learning (before) }\end{array}$} & Not Important & $\mathrm{N} / \mathrm{A}$ & $\mathrm{N} / \mathrm{A}$ & 6 & 3 & 0 \\
\hline & Some/very & $\mathrm{N} / \mathrm{A}$ & $\mathrm{N} / \mathrm{A}$ & 3 & 33 & 2 \\
\hline
\end{tabular}

Overall, students reported classmates' passion as being very similar to their own. Before the course, nearly every student in both settings expected classmates' passion to somewhat high and somewhat important to their learning. Similar results were found after the course.

Table 4: Cross tab of professor's level of passion towards individual student learning

\begin{tabular}{|c|c|c|c|c|c|c|}
\hline & & \multicolumn{2}{|c|}{ Professor's passion level (after) } & \multicolumn{3}{|c|}{ Important to learning (after) } \\
\hline \multirow{3}{*}{$\begin{array}{l}\text { Professor's } \\
\text { passion } \\
\text { level(before) }\end{array}$} & & Some/very & Passionate & $\begin{array}{c}\text { Not } \\
\text { Important }\end{array}$ & Some/very & $\begin{array}{l}\text { Extremely } \\
\text { Important }\end{array}$ \\
\hline & Some/very & 0 & 1 & $\mathrm{~N} / \mathrm{A}$ & $\mathrm{N} / \mathrm{A}$ & $\mathrm{N} / \mathrm{A}$ \\
\hline & Passionate & 10 & 36 & N/A & N/A & N/A \\
\hline \multirow{3}{*}{$\begin{array}{l}\text { Importance to } \\
\text { learning (before) }\end{array}$} & Not Important & N/A & N/A & 0 & 2 & 0 \\
\hline & Some/very & N/A & $\mathrm{N} / \mathrm{A}$ & 1 & 20 & 2 \\
\hline & Passionate & N/A & N/A & 0 & 9 & 13 \\
\hline
\end{tabular}

Before and after the course, students reported their professor's passion to be high or somewhat high. After the course, the importance of their professor's passion was considered somewhat to extremely important to their learning.

\section{DISCUSSION}

This study presents results that will be discussed within a framework of student level of passion as measured during the semester and as it changed from beginning to end of the semester.

\section{Weekly Measures of Passion}

Overall, the week-by-week measures of student passion showed wide fluctuation in their individual sense of passion and that of their classmates but not in their perception of the professor's passion.

What was consistent across both the high school and university settings was that students' passion toward engineering varied from week to week yet it never reached the highest level. There was no discernible pattern to how it varied just that it did not remain stable from one class session to the next. The most likely explanation for this, given the nature of an introductory course (i.e. survey of a wide range of topics), is that the fluctuation varies due to the particular topic. Had there been a steady decline in passion, one might assume there was a steady disengagement from the subject matter. That was not the case. In some weeks, passion went up. Given that the structure of the class remained constant, the major variable from week to week was the topic.

Student perception of their professor's passion is, perhaps, most compelling in its overall consistency and high level in both settings. It is highest in the high school setting where the professor is rarely rated below the highest level of passion. In the university setting, overall professor passion remained fairly steady between the second highest and highest level of passion. There was a dramatic drop in weeks five and six in the university setting. This could be explained by students verbalizing to the researcher that they had begun to rate the distance 
learning professors' level of passion, not the face-to-face professor. From that point on, students were reminded to rate only the professor teaching in the face-to-face portion of the class.

The slightly lower overall rating in the university setting could be explained by the fact that over the semester 21 different professors presented lectures, from a distance, prior to the face-to-face context posing confusion about which instructor to rate. Furthermore, despite a reminder to rate only the face-to-face professor, students may have averaged their rating of the two. Nonetheless, classroom observation did not reveal a distinct difference between settings in the level of passion displayed by the professor. Given the consistency from week-toweek between settings, and as observed by the researcher, the professor exuded great passion for engineering that students consistently perceived.

Despite the students' perception that their professor's level of passion was high, it did not appear to directly increase their own level of passion. It is not known how a less passionate professor might have impacted the students' passion. In this study, professor passion alone was not enough to raise and sustain student passion toward the content.

\section{Overall Change in Passion}

In examining students by passion disposition, there were no students who began or ended the class as purely dispassionate or purely passionate about engineering, learning, and in general. All students fell into a disposition that categorized them as somewhat passionate about engineering, learning, or about things in general. Given that this course was not required outside the field of engineering, it is not surprising that no students reported being disinterested in engineering upon beginning the course. Presumably, students enroll in the course because they have an interest in engineering or, at least, in learning more about it. What is surprising is that so few students reported actually being passionate about engineering upon beginning the course. Only two high school students and less than one-third of university students reported being passionate about engineering in the pre-course survey.

By the end of the course, nearly one-third of the students in the university setting became less passionate with two-thirds remaining as they began (i.e. either somewhat or highly passionate about engineering.) The downward change could be explained by the fact that some students discover that, in fact; engineering is not the field for them. While this does not appear to bode well for increasing numbers in the profession, it does point to the importance of identifying those students who are not passionate (or even somewhat passionate) about engineering as a future career. Whether those students are ultimately steered away from the field or offered supplemental support to foster greater interest in it is a subject for future discussion. It would appear that identifying them is an important first step.

In the high school setting, students' passion disposition remained remarkably stable. Only four students' dispositions changed from pre- to post. Two students became highly passionate about engineering and one became less passionate. Interestingly, the student who became less passionate was one of only two students to indicate high passion for engineering before the course. The two students who became highly passionate entered the course indicating they were somewhat passionate. This relative stability in the somewhat passionate range is likely best explained by the high school students' level of development. Though future career decisions are on the minds of university students, these decisions are not immediately pressing for high school students. It may be that high school students' views toward the profession are less volatile - either way - since they have ample time before deciding upon and committing to a major.

\section{Passion and Academic Performance}

Measures of academic performance were not taken weekly; therefore, weekly links between passion and academic performance cannot be made. Instead, students' academic performance was measured by grade on their final exam. Links between passion and academic performance were examined based on students' incoming passion disposition. Incoming predisposition to end of the semester final exam reflects the effect of overall improvement in passion on academic performance. 
Overall, students in the high school setting performed better academically than university students. In the high school setting, students who were highly passionate about engineering performed best $(M=95)$ followed by those who were somewhat passionate about engineering but not passionate about learning and most other things $(\mathrm{M}=81)$. Those students who were somewhat passionate across the board (about engineering, learning and in general) performed the lowest $(\mathrm{M}=66)$. It would appear that passion toward engineering played a role in higher academic performance.

Unlike the high school students, university students who were highly passionate about engineering scored in the mid-range $(\mathrm{M}=78)$ where students who were somewhat passionate across the board scored highest $(\mathrm{M}=83)$ with those students somewhat passionate about engineering but not passionate about learning or in general scoring the lowest $(\mathrm{M}=75)$.

Upon further examination, when looking at the change in passion disposition from pre- to post-, the decline in university students' passion toward engineering is even more intriguing. Of those students who became less passionate, $40 \%$ scored between $40-60 \%$ on their final exam but $60 \%$ scored an $81 \%$ or higher. Further studies are in order to examine whether this is a trend and, if so, why decrease in passion might increase academic performance.

\section{CONCLUSION}

The study of teaching and learning pose increasingly sophisticated questions forging new territory. What used to be the study of content and teaching technique alone, now considers the complex dynamic between learner cognition and affect. In this study, we argue that passion has a place in how we consider what it means to prepare a professional. As it relates to learning, passion can be considered on a continuum. While attention is a pre-requisite for learning, interest and engagement may not be as essential. One might pay attention to a lecture on thermodynamics but be disinterested in the subject. Engagement, which goes beyond mere interest, creates yet a deeper relationship between learner and subject matter. Studies amply demonstrate the positive benefits of engaging students in learning. By deepening student attention and interest in subject matter toward a passionate stance, passion for the content would reach the deepest state of connection to the content.

Although a clear conclusion cannot be reached based on this study due to several limitations, results of this study can be used as a framework for future studies in the area of passion as related to engineering education. This can significantly contribute to the overall learning process and success as a professional engineer.

In this study, passion was not a pre-requisite for learning. Yet, as the field of engineering education seeks to better understand how to most effectively educate its future professionals not merely to satisfactorily master content but to remain committed to the profession, learning of content may no longer be enough. Infusing passion for engineering may not only inspire students to learn, it will likely sustain them throughout their career.

\section{AUTHOR INFORMATION}

Quamrul H. Mazumder is a professor of mechanical engineering at University of Michigan-Flint. He is actively involved in engineering education research in the areas of motivation, engagement, metacognition, globalization of curriculum, assessment and evaluation. His other areas research includes computational fluid dynamics, multiphase flow and alternate energy. His 18 years of industry experience provided him with the expertise to integrate application based learning in the classroom.

Mary Jo Finney is an associate professor of education at the University of Michigan -Flint. She has an M.A.T. and $\mathrm{Ph} . D$. in Reading and Language Arts and her research centers on print and video as media for learning, reading comprehension, writing, and cognitive misconceptions in science. Previously serving as dean and director of the UM-Flint Thompson Center for Learning and Teaching, Dr. Finney is now chair of the Education Department and directs a clinically-based urban teacher preparation program. 


\section{BIBLIOGRAPHY}

1. An emerging and critical problem of the science and engineering labor force: A comparison to science and engineering indicators. National Science Foundation, 2004. http://www.nsf.gov/statistics/nsb0407.

2. Project Kaleidoscope Report on Reports-2002 Recommendations for Action in support of Undergraduate Science, Technology, Engineering, and Mathematics http://www.pkal.org

3. Project Kaleidoscope Report on Reports II: Recommendations for Urgent Action, 2006 "Transforming America's Scientific and Technological Infrastructure" http://www.pkal.org

4. Palmer, P. The courage to teach. San Francisco, CA: Jossey-Bass, 1998

5. Brookfield, S. Becoming a critically reflective teacher. San Francisco: Jossey-Bass. 1995

6. Felder, R. M. \& Silverman, L. K. Learning and teaching styles in engineering education. Engineering Education, 78(7), 674-681. 1988

7. Heing, T. L., \& Budny, D. D. Teaching to students' learning styles: Approaches that work. Paper presented at $29^{\text {th }}$ ASEE/IEEE Frontiers in Education Conference. San Juan, Puerto Rico. 1999

8. Higley, K. A. \& Marianno, C. M. Making engineering education fun. Journal of Engineering Education, 105-107. 2001

9. French, B. F., Immekus, J. C., \& Oakes, W. C. An examination of indicators of engineering students' success and persistence. Journal of Engineering Education, 94(4), 419-425. 2005

10. Prince, M. "Does active learning work? A review of the research." Journal of Engineering Education, 93(3), 223-231. 2004

11. Dunlap, J. C. "Problem-based learning and self-efficacy: How a capstone course prepares students for a profession." Educational Technology Research and Development, 53(1), 64-85. 2005

12. Davies, C. H. J. "Student engagement with simulations: A case study." Computers \& Education, 39, 271282. 2002

13. Bjorklund, S. A., Parente, J. M., \& Sathianathan, D. “ Effects of faculty interaction and feedback on gains in student skills." Journal of Engineering Education, 153-160. 2004

14. Pomales-Garcia, C., \& Liu, Y. “Excellence in engineering education: Views of undergraduate engineering students." Journal of Engineering Education, 253-262. 2007

15. Turns, J., Eliot, M., Neal, R., \& Linse, A. "Investigating teaching concerns of engineering educators." Journal of Engineering Education, 295-308. 2007

16. Ainley, M. "Connection with learning: Motivation, affect and cognition in interest processes." Educational Psychology Review, 18, 391-405. 2006

17. Ainley, M., Hidi, S., \& Berndorff, D. "Interest, learning, and the psychological processes that mediate their relationship." Journal of Educational Psychology, 94(3), 545-561. 2002

18. Cordova, D. I. \& Lepper, M. R. "Intrinsic motivation and the process of learning: Beneficial effects of contextualization, personalization, and choice." Journal of Educational Psychology, 88(4), 715-730. 1996

19. Sylvia, P. J. "What is interesting? Exploring the appraisal structure of interest". Emotion, 5(1), 89-102. 2005

20. Felder, R. M., \& Brent, R. The intellectual development of science and engineering students: Part one: Models and challenges. Journal of Engineering Education, 269-277. 2004

21. Patton, M. Q. "Qualitative research \& evaluation methods." Thousand Oaks, CA: Sage. 2002 


\section{APPENDIX 1}

Pre/ Post-Test Questionnaire for Student Assessment of Passion

Please read each of the following statements and circle one of the responses (1-4) that most closely represents your current thinking.

What is your current level of interest in engineering?

$\begin{array}{cccc}\mathbf{1} & \mathbf{2} & \mathbf{3} & \mathbf{4} \\ \text { Not very } & \text { Somewhat interested } & \text { Very interested } & \text { Passionate } \\ \text { interested } & & & \end{array}$

What do you imagine most of your classmates' level of interest in engineering to be?

$\begin{array}{cccc}\mathbf{1} & \mathbf{2} & \mathbf{3} & \mathbf{4} \\ \begin{array}{c}\text { Not very } \\ \text { interested }\end{array} & \text { Somewhat interested } & \text { Very interested } & \text { Passionate }\end{array}$

What do you imagine your professor's level of interest in engineering to be?

\section{1}

Not very

interested
2

Somewhat interested

Very interested

4

Passionate

In describing myself, I would say I am:

\section{1 \\ 2}

Not very passionate about anything
Somewhat passionate about some things
3

Passionate about most things
4

Very passionate about everything

How important is it to you that you are passionate about what you are learning?

1

Not Important

\section{2}

Somewhat important
3

It's nice but not necessary
4

I cannot learn if I am not passionate about what I am leaning

How important to your learning is your professor's level of passion about engineering?

1

Not Important
2

Somewhat important
3

Important
4

I cannot learn if my professor is not passionate

How important to your learning is your classmates' level of passion about engineering?

1

Not Important
2

Somewhat important
3

Important
4

I cannot learn if my classmates are not passionate

Please rank each of the following ( $1=$ least and $5=$ most) based on what you believe will have the greatest effect on your passion for engineering:

The topics each class period

The quality of materials (reading, handouts, powerpoint)

My professor's level of passion about engineering

My professor's level of knowledge about engineering

My classmates' level of passion about engineering 
Please rank each of the following ( $1=$ least and $5=$ most) based on what you believe will have the greatest effect on your success in learning engineering:

The topics each class period

The quality of materials (reading, handouts, powerpoint)

My professor's level of passion about engineering

My professor's level of knowledge about engineering

My classmates' level of passion about engineering

Besides the list above, please list anything else you feel might affect your passion for engineering:

Besides the list above, please list anything else you feel might affect your learning about engineering: 